$\begin{array}{cc}\text { Tür Coğrafya Dergisi } & \text { Turkish Geographical Review } \\ \text { Basılı ISSN 1302-5856 } & \text { www.tcd.org.tr }\end{array}$

\title{
Gaziantep ili ihracatının coğrafi çeşitliliği
}

\section{Geographical diversification of Gaziantep province exports}

\author{
Ömer Şen *a \\ ${ }^{a}$ Gaziantep Üniversitesi, Fen Edebiyat Fakültesi, Coğrafya Bölümü, Gaziantep, Türkiye.
}

ORCID: Ö.Ş. 0000-0002-1769-8236

\begin{tabular}{|c|c|}
\hline BILGi / INFO & ÖZ / ABSTRACT \\
\hline Geliş/Received: 19.03.2021 & \multirow{9}{*}{$\begin{array}{l}\text { İhracatın artııılması, bilhassa gelişmekte olan ülkelerin her ölçekteki coğrafi birimi için ekonomik } \\
\text { kalkınmada kilit bir araçtır. İhracat miktarının; yerel, bölgesel ve küresel ihracatın oranının ve ürün } \\
\text { çeşitliliğinin bilinmesi kadar, ihracatın hangi pazarlara yapıldığının yani coğrafi çeşitliliğin bilinmesi } \\
\text { de büyük önem arz etmektedir. Gaziantep, Türkiye'nin en yüksek ihracat yapan illeri arasındadır. } \\
\text { Bu çalışma, 2010-2019 yılları arası Gaziantep ihracatının coğrafi çeşitliliğini Hirschman-Herfhindal } \\
\text { İndeksi (HHI) kullanılarak ölçmek ve sonuçlarını değerlendirme amacı taşımaktadır. Ayrıca ilin ihra- } \\
\text { cat gerçekleştirdiği pazarlardaki yoğunlaşma durumunu tespit etmek ve coğrafi çeşitlilik bulgularını } \\
\text { daha kapsamlı bir şekilde açıklamak amacıyla Ticaret Yoğunlaşma İndeksi (TII) de kullanılmıştır. } \\
\text { Son on yıllık dönemde ilin HHI değeri yaklaşık yarı yarıya düşüş göstererek, coğrafi çeşitliliğin art- } \\
\text { tığı gözlenmiştir. En yüksek TII değerleri ise coğrafi yakınlık avantajları ve tarihi kültürel bağları } \\
\text { ile Ortadoğu ülkelerinde gözlenmiştir. Bunun yanında Afrika ve Orta Asya pazarlarında da alanını } \\
\text { genişletmekle birlikte, Birleşik Krallık ve İtalya gibi ithalat rakamları yüksek Avrupa ülkelerinde de } \\
\text { ortalamalara yaklaşan değerler göstermiştir. Coğgafi çeşitliliğin artş̧ göstermesinde Gaziantep'te } \\
\text { oluşan ve giderek gelişen çok aktörlü bir ihracat değer ortamı ile firmaların yüksek rekabet ile daha } \\
\text { yüksek oranda yeni pazar arayışlarının etkisi olduğu söylenebilir. }\end{array}$} \\
\hline Kabul/Accepted: 01.06.2021 & \\
\hline Anahtar Kelimeler: & \\
\hline Coğrafi çeşitlilik & \\
\hline inracat & \\
\hline & \\
\hline $\begin{array}{l}\text { Keywords: } \\
\text { Gaziantep }\end{array}$ & \\
\hline Geographical diversification & \\
\hline Export & \\
\hline
\end{tabular}

*Sorumlu yazar/Corresponding author:

(Ö. Şen) omersen@gantep.edu.tr.

DOI: $10.17211 / \mathrm{tcd} .899402$

\section{Atff/Citation:}

Şen, Ö. (2021). Gaziantep ili ihracatının coğrafi çeşitliliği. Türk Coğrafya Dergisi, (77), 145-156. https://doi.org/10.17211/tcd.899402
Increasing exports is a key tool in economic development, especially for geographical units of all sizes of developing countries. It is just as important to know its geographical diversification; to know the amount of exports, to know its ratio to local regional and global exports, to know the diversity of products. Gaziantep is among the highest exporting provinces of Turkey. The aim of this study is to measure the geographical diversification of Gaziantep exports between 2010-2019 using Hirschman-Herfhindal Index (HHI) and to evaluate its results. In addition, the Trade Concentration Index (TII) was also used to determine the concentration status in the markets in which the province exports and to explain the geographical diversity findings in a more comprehensive way. During the last decade, the HHI value of the province has decreased by about half, increasing the geographical diversification of the province. It has emerged in Middle Eastern countries with the highest TII values, geographical proximity advantages and historical cultural ties. In addition, it also expanded its field in African and Central Asian markets, but also showed values approaching the average in European countries with high import figures, such as the United Kingdom and Italy. In the emergence of this situation, it can be said that with a multi-actor export value environment, firms have a high competition and a higher rate of new markets search.

\section{Extended Abstract Introduction}

In the study of economic activities, geographers focus on the location of production, distribution and consumption and its interactions with the human and physical environment. Exports bring about a positive transformation in the economic geography landscape by supporting employment, increasing the labour market and the accumulation of capital.
Diversification of foreign trade as much as possible has also been one of the proposed policies for export-based sectors and enterprises, and therefore local economies, to reduce demand risks arising from foreign trade (Çınar \& Göksel, 2010; Değer, 2010; Taş, 2011).

There are two ways to diversify foreign trade. The first is to increase the product portfolio in existing markets with high added value and the most competitive methods possible. The 
second is to increase export markets in geographies that can stay there for a long time and have the potential to be/have a stable economic structure.

Gaziantep, the ninth largest province in Turkey by population, ranks sixth in exports and is one of the leading cities of local industrialization (Sandal \& Şen, 2016; Ayık \& Enterili, 2020). The city, which has an unbeatable position in the region with economic indicators, is also an important export base for Turkey.

In this study, it is aimed to measure and evaluate the results of the trade Concentration Index (TII), which is the geographical diversity of Gaziantep's exports and the share it receives from total imports in the countries it exports to. In the literature, it is seen that the geographical concentration studies that focus on the city are only considered indirectly. In this sense, the direct urban focus of this study also expresses value for urban geography and urban economies in the context of industrial geography.

\section{Assessment of the Literature}

Studies on geographical diversification have two main areas of discussion. These are: product diversity and geographic diversity (Shepotylo, 2013; Akar \& Ay, 2019). It seems that studies carried out on the axis of geographical diversification follow a course, mainly in the form of benchmarking on the basis of countries or regions, or studying the geographical diversification of a country between certain periods. Although geographic diversity studies are found at the regional scale, there are almost no direct urban-level studies.

\section{Data and Method}

In this study, the geographical diversification of exports from Gaziantep province was measured between 2010 and 2019 with the Hirschman-Herfindahl index (HHE), which is a frequently used Diversification Index in the literature and is also frequently used in competition analysis in accordance with the geographical diversity index.

Although it is possible to measure both sectoral and geographic diversity with this index, the following formula is used to measure geographic diversification:

$$
(H H E)=\sum_{k} p 2_{i k}
$$

The trade Intensification Index (TII), which complements the HHE index used to measure geographic diversification and makes it more inclusive, was also included in the study. The trade Concentration Index TIlij is calculated as follows:

$$
T I I_{i j}=\left(X_{i j} / X_{i}\right) /\left(M_{j} / M_{d}\right)
$$

The data obtained in the study were obtained from the World Trade Organization (WTO), the Ministry of trade of the Republic of Turkey and the Turkish Exporters Assembly (TIM). The data obtained are processed on the map using ArcGIS 10.3 program and spatial distribution values are shown.

\section{Analyses and Findings}

Between 2010 and 2019, the geographical diversification average ( $\mathrm{HHI}$ value) of exports from Gaziantep province was measured as 0.1093 . The index value, which was 0.1281 in the first year of measurement, fell to 0.573 in the last year of measurement and decreased by half in the said period. Although there has been a negative diversification in 2010, 2011 and 2012, there has been a steady positive geographic diversity since 2012. This indicates that the diversity of the country in exports from Gaziantep has increased significantly, especially over the last seven years.

Considering the course of the last ten years of the country that ranks first in exports and the share that the top five countries receive from Gaziantep exports, the share values show a decline in both periods.

Looking at the TII values, it is seen that countries with high values extend to three main blocks on the axis of geographical proximity. These are: Middle East, Africa and Europe (Figure 5). The country with the highest TII value is Syria. In TII, Syria is followed by Iraq and Somalia. However, the inclusion of two European countries such as Italy and the United Kingdom, which have a high import rate, in the index is an important parameter for Gaziantep exports.

\section{Results and Discussion}

In Gaziantep, which performed better than Turkey's export performance between 2010 and 2019, the diversity of exported countries tends to increase significantly. As a reason for this situation, a multi-actor export ecosystem formed in the province can be shown by companies looking for new markets with more proactive behaviour strategies as a result of specialization and increased competition throughout the province.

The city, which is an important cluster place, especially in the field of machine carpets and industrial textiles, has evaluated the competitive advantages of this situation in the best way. This industrial cluster also attracted skilled labour and human capital, making it the sixth largest export city in the country, located in the most disadvantaged region of the country.

Risks such as low productivity, production concentration in several sectors, low geographical diversity in exports, concentration in weak income import markets, and doing business in strategic conflict areas are seen as negative scenarios for the future of the city.

Product diversity and product quality are important in exports. But it is also important to increase the number of countries exported as qualified. For export locations in a world that is extremely fragile and contains past economic, political and social risks, this is a way that they must inevitably resort to minimizing risks. Finally, besides the sectoral and productbased assessments, the geographical framework drawn by exports and the limits, limitations and dimensions of this framework are known and all kinds of future projections should be considered in this integrity as a matter that should not be neglected. 


\section{Giriş}

Ekonomik faaliyetlerin incelenmesinde coğrafyacılar, üretim, dağıtım ve tüketimin lokasyonu ile bunun beşeri ve fiziki ortamla olan etkileşimleri üzerine odaklanırlar. Buradaki temel iki nokta, dağılış ve bunun meydana getirdiği dönüşümdür. İhracat konusuna Coğrafya'nın bakış açısı, bilim dalını ilgilendiren başlıca ilgi odakları olan dağılış düzeni, yerleşmiş oldukları alandaki çeşitli elemanlarla etkileşimi ve mekânların birbirleri ile olan bağlantıları üzerinden olmaktadır (Tümertekin \& Özgüç, 1997; Coe vd., 2007; Doğanay vd. 2020; Doğan, 2021). Ihracat, yerelden küresele hangi coğrafi ölçekte gerçekleşirse gerçekleşsin, söz konusu mekân için önemli bir ekonomik gelişim aracıdır. İstihdamı destekleyerek işgücü piyasasında, sermeye birikimini artırarak ekonomik coğrafya manzarasında olumlu bir dönüşümü beraberinde getirir.

İhracatın miktarı, ihraç mallarının ürün çeşitliliği ve kalitesi ihracatın önemli değişkenleridir. Bunların yanında ihracatın hangi pazarlara gerçekleştirildiği yani coğrafi çeşitlilik de bir diğer önemli değişkendir (Erlat \& Akyüz, 2001; Kaplan \& Tur, 2017; Cos vd., 2019). Dış ticareti çeşitlendirmenin iki yolu vardır. Birincisi mevcut pazarlardaki ürün portföyünü katma değeri yüksek ve mümkün olan en rekabetçi yöntemlerle artırmak, ikincisi ise ihracat pazarlarını, orada uzun süre kalabilecek şekilde ve istikrarlı ekonomik yapıya sahip olan veya olabilme potansiyeline sahip coğrafyalarda artırabilmektir.

Küreselleşme olgusunun kendisi hissettirdiği bir dönemde, artkk sadece yerel değil global ölçekte gerçekleşen olaylar da kısa sürede ihracat gibi kırılganlığı yüksek kalemleri doğrudan etkileyebilmektedir. Buna bağlı olarak coğrafi ünitelere pozitif veya negatif yönde etkileri söz konusu olmaktadır. Bu duruma karşı ihracat gerçekleştiren her bir coğrafi birim, ihracat yaptı̆ı ülke sayısını artırmayı dış ticareti için bir sigorta olarak değerlendirmektedir (Shepotylo, 2013). Coğrafi çeşitliliği artırmak, ihracatın yapıldığı ülke özelinde mevcut ve muhtemel riskleri aza indirmektedir. Bir ülke veya bölgeden sınırlı sayıda ülkeye ihracat yapılıyorsa, bu yerin ihracat pazarında yoğunlaşma yaşandığı, başka bir ifadeyle coğrafi çeşitlilik düzeyinin artırılamadığı sonucuna varılır. İhracatta coğrafi yoğunlaşma olarak isimlendirilen bu durum, ihracatçı ülkenin dış ticaret gelirini negatif yönde etkileyebilmektedir (Kösekahyaoğlu, 2007; Değer \& Genç, 2010; Erkan \& Sunay, 2016).

Tarihi oldukça eskilere dayanan bir kent olan Gaziantep, Mümbit Hilal'in kuzeybatı ucunda Anadolu'yu Ortadoğu'ya bağlayan stratejik bir coğrafi konumda yer almaktadır. Tarihsel süreçte üretkenliğinin verdiği zenginlik, kenti bir alım-satım merkezi haline getirmiş, Cumhuriyet'in ilanından sonra da Halep ve Şam gibi iki önemli ticaret şehrinin hinterlandında bulunması ve bu şehirlerin sınırlarımız dışında kalması ile ortaya çıkan boşluğu doldurarak bölgesel bir ticaret merkezi haline gelmiştir (Mortan \& Arolat, 2009; Arınç, 2011). Kent geçmişinden gelen ticaret birikimini, Cumhuriyet Döneminde sanayi faaliyetlerini de içine alacak şekilde genişletmiştir. Gaziantep, sanayi odaklı asıl gelişimini Cumhuriyet sonrasındaki dönemde gerçekleştirmiştir (Sönmez, 2012; Özlü-Yıldız, 2017; Dinçer, 2019). Sanayinin gelişmesi ile özellikle çevre illerden ve kendi taşrasından göç almaya başlamıştır. (Ulusoy \& Turan, 2016). Göçle birlikte bilhassa Güney Doğu ve Doğu Anadolu Bölgesi'nin diğer illerinden sermaye çekmeyi başarmış ve hızlı bir sanayileşme sürecine girmiştir. Coğrafi sınırlılıkları, verimli tarım alanlarının yetersizliği, devlet yatırımlarının azlığı gibi olumsuz koşullara rağmen, süreç içinde kent önemli bir yol almış ve firmalar belirli sektörlerde önemli ölçüde uzmanlaşma becerisi göstermiştir (Söylemez vd., 2012).

Gaziantep, ülkenin kalkınmada geri kalmış bir bölgesindedir. Ancak bulunduğu bölge içerisinde en yüksek gelişmişlik düzeyini yakalayan il de Gaziantep'tir (Ünsal \& Sülkü, 2020). illeri gelişmişlik sıralamasına göre alt gruba ayırdıkları çalışmalarında Ünsal ve Sülkü (2020), Güneydoğu Anadolu Bölgesi illerinden sadece Gaziantep'i "ortalamaya yakın” iller kategorisinde almışlar, bölgenin diğer illerini ise "düşüğe yakın" ve "düşük" kategorilerde yer vermişlerdir. Aynı çalışmada 81 il arasından Gaziantep üretim açısından üçüncü, kazanç açısından birinci sırada yer almıştır.

Bu çalışmada, Gaziantep'in yapmış olduğu ihracatın coğrafi çeşitliliği, Hirschman-Herfhindal Endeksi (HHI) ile; ihracat yapt̆ğı ülkelerde o ülkelerin toplam ithalatından aldığı payı ise Ticaret Yoğunlaşma İndeksi (TII) ile ölçülmesi ve sonuçlarının değerlendirilmesi amaçlanmaktadır. Literatürde odağına kenti alan coğrafi çeşitlendirme çalışmalarının dolaylı olarak ele alındığı görülmektedir. Bu anlamda çalışmanın doğrudan kent odaklı olması, sanayi coğrafyası bağlamında kent coğrafyası ve kent ekonomileri için de bir değer ifade etmektedir. Bu bağlamda çalışmanın önemli bir boşluğu doldurma potansiyeline de sahip olduğu düşünülmektedir. Yalnızca sektörel çeşitlilik ve niceliksel artışın değil, bu kompozisyonda ihracatın fasıl çeşitliliği ve ihracat yapılan ülkedeki coğrafi çeşitliliğin payı da bir başka çalışmanın konusu olarak incelemeye değer bir husus olarak karşımızda durmaktadır.

Çalışma, ihracatta coğrafi çeşitliliğin yeri ve önemini açıklayan "Giriş" bölümü ile başlamaktadır. Ayrıca bu bölümde, Gaziantep Sanayii'nin Türkiye ve Bölge ekonomisi içindeki yerine de değinilmiştir. İkinci bölümde, ihracatta coğrafi çeşitlilik çaIışmalarının literatürde yeri ve önemine değinilerek bu çalışmanın literatürde dolduracağı boşluk ifade edilmiştir. Üçüncü bölümde ise Gaziantep ilinin coğrafi çeşitliliğinin ve ithalatçı ülkelerin toplam ithalatından aldığı payın hesaplanmasında kullanılan yöntem ve materyal açıklanmış, yöntemlerin tercih sebepleri ve sınırlılıkları da ifade edilmiştir. Dördüncü bölüm ise çalışma sonucu elde edilen coğrafi çeşitlilik ve ticari yoğunlaşma bulguları açıklanmış, bu bulgulara göre bir analiz çerçevesi çizilmiştir. Son bölümde ise çalışma sonucu elde edilen bulgular literatür ile ilişkilendirilerek çalışmadan elde edilen sonuçlar tartışılmıştır.

\section{Literatür Değerlendirmesi}

Coğrafi çeşitlenme konusunda yapılan çalışmaların iki temel tartş̧ma alanı vardır. Bunlar: ürün çeşitliliği ve coğrafi çeşitliliktir (Shepotylo, 2013; Akar \& Ay, 2019). Ürün çeşitliliği, ihraç edilen mal ve hizmetlerin nicelik ve niteliğinin, mevcut ihraç pazarlarında rekabetçi bir yapıda artırımasını, coğrafi/pazar çeşitlendirme ise ihraç edilen ürün ve hizmetlerin daha fazla sayıda ülke veya bölgeye mümkün olan en kalıcı şekilde ihraç edilmesini ifade eder. Ürün ve coğrafi çeşitlilik üzerine yapılan çalışmaların daha çok ekonomik büyüme ve GSYiH ile olan ilişkileri, gelişmekte olan ülkeler üzerinde etkileri, coğrafi çeşitliliği etkileyen faktörler, firmalar üzerindeki etkileri gibi konulara odaklanan 
çalışmalar olduğu görülmektedir (Aldan vd., 2012; Agosin vd., 2012; Azgün \& Takım, 2016). Coğrafi çeşitlilik ekseninde gerçekleştirilen çalışmaların, daha çok ülke veya bölge bazında kıyaslama veya bir ülkenin coğrafi çeşitliliğinin belirli dönemler arasında incelenmesi şeklinde bir seyir izlediği görülmektedir. Bölgesel ölçek de coğrafi çeşitlilik çalışmalarına rastlansa da doğrudan kent düzeyinde çalışmalar yok denecek kadar azdır.

Dış ticaretin en önemli bileşenlerinden biri olan ihracat hacmi, son yıllarda en fazla dikkat çeken makroekonomik unsurlardandır (Erkan, 2012). ìhracatın coğrafi çeşitliliğinin artırılmasının artan önemi nedeniyle büyüme, kalkınma ve refah düzeyi artşları ile bağlantılı çok sayıda çalışma gerçekleştirilmiş ve bu çalışmalar coğrafi çeşitliliğin artırımasının kişi başına düşen gelirin ivme kazanması ile bağlantılı olduğunu ortaya koymuştur (Lederman \& Maloney, 2009; Hesse, 2009). İhracat çeşitlendirmesi, dış ticaret kaynaklı talep risklerini azalttı̆ı için ve daha istikrarlı bir gelir girişi yaratma avantajına sahip olması nedeniyle sıklıkla önerilen politikalardan birisidir (Al Marhubi, 2000; Amurgo-Pacheco \& Pierola, 2008; Çınar \& Göksel, 2010; Değer, 2010; Taş, 2011).

Ihracatta coğrafi çeşitlendirmenin, dünya pazarlarındaki rekabeti teşvik ettiğini, yaparak öğrenme ve ihracat yoluyla öğrenme dışsallıklarının, ekonomik büyüme ile bağlantılı olduğunu ve ekonomik büyümede önemli bir rol oynadığını göstermektedir (Herzer \& Lehnmann, 2006; Agosin, 2009; Didier, 2017). Kapsamlı bir marjda coğrafi çeşitliliğin, bilhassa gelişmekte olan ülkeler için ürün çeşitlendirmeden daha önemli olduğu gözlenmektedir (Amurgo-Pacheco \& Pierola 2008). Ayrıca ihracat lokasyonlarını daha çok çeşitlendirmiş sektörlerin, ihracat bakımından daha sürdürülebilir bir yapıya kavuştuklarını ortaya koymuştur (Torlak vd., 2007; Shepherd, 2010; Çınar \& Göksel 2010; Yaşar, 2019).

Yapılan çalışmalarda, GSYiH ile ihracatta coğrafi çeşitlilik ve toplam ihracat arasında karşılıklı ve istatistiki olarak anlamlı ilişkiler gözlenmiştir (Brenton vd., 2009; Değer \& Genç, 2010). Ülkelerin ihracatın çeşitlendirilmesine ve bileşimine odaklanan, ticaret ve büyüme ilişkisini analiz eden çalışmalarda, bir ülkenin ihracat dünya ortalama ihracatından daha fazla olduğunda, ihracat çeşitlendirmesinin etkisinin daha güçlü olduğunu göstermesi nedeniyle ihracat seviyesinin dikkate alınması gerektiğini ortaya koymaktadır (Aditya \& Acharyya, 2011; Aldan vd., 2012). Dış ticarette coğrafi ve ürün çeşitliliğinin ihracatçı firmaların performansına yaptıkları etkileri odağına alan çalışmada ise coğrafi çeşitliliğin ortaya çıkardığı gelirlerin, ürün çeşitlemesine göre daha fazla olduğunu ortaya koymuştur (Dalgıç \& Fazlıoğlu, 2015).

Literatürde finansal kalkınmanın ülkelerin ihracatlarını çeşitlendirmelerine yardımcı olmadığına, döviz kurlarının oynaklığının ihracat çeşitlendirmesi üzerindeki olumsuz etkisi olduğuna, beşeri sermaye birikiminin ihracat çeşitlendirmeye olumlu katkı yaptığına ve uzaklığın artmasının ihracat çeşitlendirmesini azaltma eğiliminde olduğuna (Agosin vd., 2012; Yaşar, 2019), coğrafi ihracat çeşitlendirmesinin GSYiH büyümesi ile daha düşük bir ilişkiye işaret ettiğine dair ampirik kanıtlar da sunulmaktadır (Siddiqui, 2018).

Coğrafi çeşitlendirme stratejisi uygulayan firmaların, ihracat pazarlarını farklı coğrafi lokasyonlara yayması (ilişkisiz coğra- fi çeşitlendirme), ihracat pazarlarında etki gücünü, inovasyon vizyonunu, sermaye çekme kapasitesini ve işgücü performansını olumlu olarak etkilediğini ortaya koymuştur (Öztürk \& Anıl, 2017). Ayrıca ilişkili veya ilişkisiz coğrafi çeşitlendirmenin, ihracatçı firmaların coğrafi çeşitlendirmenin gelecekteki ürün çeşitliliğini artırma eğiliminde olduğu sonucuna da ulaşılmaktadır (Boehe \& Jimenez, 2018).

Cumhuriyetin ilk yıllarından itibaren Türkiye'nin dış ticareti çok çeşitli süreçlerden geçmiş ve genel hatlarıyla politik tercihler dışa açılma ve global sistemle bütünleşme çerçevesinde gerçekleştirilmiştir (Özdemir vd., 2016). 1980'den itibaren neoliberal ekonomi politikaları ekseninde dışa açık ve ihracat odaklı bir sanayileşme ve büyüme tercihi yapılmıştır. Bu tercihlerin bir sonucu olarak 1980'den itibaren serbest dış ticaret ekseninde, geleneksel ürünlerden yüksek teknolojili ürünlere, geleneksel dış ticaret lokasyonlardan alım gücü daha yüksek olan yeni lokasyonlara bir yönelme gerçekleşmiş; sanayi mallarının çeşitliliğinde artışlar, üretimde rekabet ve döviz gelirlerinde sürekli artışlar sağlanmıştır (Kösekahyaoğlu, 2007; Akal, 2008). Ekonomi politikalarında görülen bu keskin değişim, hızlı bir küresel dönüşüm yaşayan dünyada, Türkiye'ye yeni hedefler belirleme zorunluluğunu getirmiştir (Avcl, 2000).

Türkiye ihracatının uzun vadeli ve nedensellik ilişkileri bağlamında ekonomik kalkınması ile ürün çeşitlendirmesi arasındaki ilişkiye bakıldığında, ekonominin dışa açıklığı arttıkça ürün çeşitliliğinin de arttı̆ı, bununla birlikte diğer değişkenler arasında anlamlı bir bağlantının bulunamadığı ve ileriki dönemlerde coğrafi çeşitliliği artırarak ihracatı yükseltebilmenin daha düşük bir intimal olacağı belirtilmiştir (Acaravcı \& Kargı, 2015; Kaplan \& Tur, 2017).

Türkiye'nin yakaladığı olumlu ihracat ortamının coğrafi çeşitlilik ile bağlantısının yüksek olduğu, ancak hala geleneksel ihracat lokasyonlarının dış ticarette önemli bir yer işgal ettiği vurgulanmaktadır (Türkcan, 2014). Dış ticaretin kapsamlı bir dönüşümünün hem coğrafi çeşitlilik hem de nitelikli ürün çeşitlendirmesi ile gerçekleşeceği de ortaya konulmaktadır (Kaplan \& Tur, 2017). Türkiye'nin dış ticaretinde coğrafi çeşitlenmenin durumunu konu edinen çalışmalarda, Gümrük Birliği sonrasında ülke ve fasıl bazlı değişimlerin ülke bazında hem ithalatta hem ihracatta ilk dört sırada yer alan ülkeleri kapsayan CR4 oranında bir değişiklik olmadığını (Doğan \& Soyyiğit-Kaya, 2011), iki binli yıllardan sonra Türkiye'nin dış ticaretinde büyük artış yaşadığı bazı Ortadoğu ülkeleri arasında ticari yoğunluğun artş̧ gösterdiğini (Demir, 2020), Türkiye'nin ihracatında ilk beş ülkenin sahip olduğu payın azalarak coğrafi çeşitlenmenin arttı̆ının (Akar \& Ay, 2019), AB ülkeleri ile gerçekleştirilen dış ticaretin coğrafi olarak homojen bir dağılım gösterdiğini ve global sistemde rekabet avantajları sağlandığını ortaya koymaktadır (Erkan \& Sunay, 2016; Yılmaz \& Akkaya, 2020).

\section{Materyal ve Yöntem}

Coğrafi çeşitliliği ölçmede, basit hesaplanabilmesi nedeniyle Yoğunlaşma Oranı Analizi (CR) (Akardeniz \& Kıraç, 2015), toplam bölgesel çeşitlendirmeyi ülke grupları içinde ve gruplar arasında olmak üzere bileşenlere ayırarak ölçmeye yarayan Entropi Endeksi (Çınar \& Göksel, 2010), bir ülkenin dış ticaretindeki ürün veya ülke dağılım oranını gösteren Gini-Hirschman katsayısı (Azgün \& Takım, 2016), daha çok ülkelerin/böl- 
gelerin birbirleri ile karşılaştırılırken kullanılan ve özellikle alt gruplarının eşitsizliğini ölçmek için tercih edilen Theil Entropy İndeksi (Orhan \& Demir, 2019), HHI endeksinin yüzdesel olarak ifade edilmesini ve daha karşılaştrılabilir bir hal almasını sağlanan Herfindahl-Hirschman-Agiobenebo Endeksi (Öztürk, 2005), birimlerin pay sırasını dikkate alarak ölçeklendiren bir endeks olan Hall-Tidemann endeksi (Yılmaz \& Akkaya, 2020) gibi çok çeşitli yöntemler kullanılmaktadır.

Bu çalışmada Coğrafi Çeşitlilik Endeksi ile uyumlu olarak literatürde sıkça kullanılan çeşitlilik endeksi olan ve aynı zamanda rekabet analizlerinde de sıkça kullanılan Hirschman-Herfindahl Endeksi (HHI) ile Gaziantep'ten yapılan ihracatı 20102019 yılları arasındaki coğrafi çeşitliliği ölçülmüştür. Bu endeksin seçilme sebebi doğrudan ülkelerin paylarını dikkate alan yapısı sebebiyle, diğer yoğunlaşma göstergelerine de temel teşkil edebilmesidir (Yayla, 2007). Endeksin, "bütün ürünleri ya da ülkeleri kapsaması ve piyasa payı büyük olan birimlere daha fazla ağırlık vermesi sebebiyle, teorik açıdan daha üstün olduğu düşünülmekte; diğer taraftan hesaplanan indeks değerinin birimlerin tek tek büyüklüğünü yansıtmaması da bir dezavantaj olarak değerlendirilmektedir" (Soyyiğit \& Doğan, 2019: 169). Bu çalışmada bu sınırlılığı minimize etmek amacıyla HHI endeksine ek olarak Ticaret Yoğunlaşma Endeksi de (TII) kullanılmıştır.

İlk olarak Hirscman (1945) tarafindan geliştirilen yöntem daha sonra ondan bağımsız olarak Herfindal (1950) tarafindan da kullanıldığı için endeks iki akademisyenin adını taşımaktadır (TEPAV, 2016). Bu endeks ile hem sektörel hem de coğrafi çeşitliliği ölçmek mümkün olmakla birlikte coğrafi çeşitliliği ölçmek için aşağıdaki formül kullanılır:

$$
(H H I)=\sum_{k} p 2_{i k}
$$

k ülkesinin, i ilinin toplam ihracatından aldığı pay $P$ ik ile gösterilmek üzere, ülkelerin ilin toplam ihracatından aldıkları payların karelerinin toplamıdır ve endeks maksimum 1 değerini alır. Endeks değerinin 1'e yakın olması ihracatın belli ülkelerde yoğunlaştığını ve ihracatta riskin arttğını gösterirken, 0’a yakın değer alması ise ihracatın geniş ülke ve ürün yelpazesine yayıldığını, coğrafi çeşitliliğin arttı̆ını ve riskin dağıtıldığını ifade eder (TiM, 2020). HHI endeksi hesaplanırken en fazla ihracatın yapıldığı ilk beş veya on ülke temel alınarak gerçekleştirilir. Bu çalışmada sonuçların daha kapsamlı ve açıklayıcı olması amacıyla en fazla ihracatın gerçekleştirildiği ilk on ülke esas alınmıştır.

Coğrafi çeşitliliği ölçmek için kullanılan HHI endeksini tamamlayan, daha kapsayıcı bir hale getiren ve sınırlılıklarını kapatan Ticaret Yoğunlaşma Endeksi (TII) de çalışmaya dahil edilmiştir. Ticaret yapan iki tarafin dünya ihracatı ve ithalatındaki önemini dikkate alarak, ihracatçı ülkenin, ithalatçı pazarda ne derece yoğunlaştı̆ı̆ı ölçmek için TII Endeksi kullanılır (TEPAV, 2020). TII endeksi; iki ülke arasındaki ticaretin değerinin, dünya ticaretindeki önemleri temelinde beklenenden daha büyük ya da küçük olup olmadığının belirlenmesine yardımcı olmaktadır (Demir, 2020). Hesaplanan değerler "bir ülkenin veya şehrin; belirli bir bölge ya da ülke grubunu dünyanın geri kalanına göre -ihracatında- daha fazla tercih edip etmediğini (daha fazla yoğunlaşıp yoğunlaşmadığı) açıklamaya çalışan bir endekstir" (Saray, 2019: 184). Ayrıca endeks, dış ticarette "coğrafi uzmanlaşma" bulunmayan varsayımsal bir ülkeler dünyasında hüküm sürecek olan ticaret akışına karşı fiili ticareti değerlendirmesi açısından da önem arz etmektedir (Edmonds \& Li, 2010: 4). Brown (1949) tarafindan ilk kez kullanılan endeks, Kojima (1964) ve daha sonra ve Kunimoto (1977) tarafindan geliştirilerek yaygınlaştırılmıştır (Saray, 2019). Ticaret Yoğunlaşma Endeksi TIlij aşağıdaki gibi hesaplanmaktadır:

$$
T I I_{i j}=\left(X_{i j} / X_{i}\right) /\left(M_{j} / M_{d}\right)
$$

Formülde; Xij i ilinin j ülkesine ihracat, Xi i ilinin toplam ihracat, $\mathrm{Mj}$ j ülkesinin toplam ithalat, Md dünyanın toplam ithalat olmak üzere, i ilinin j ülkesindeki ticaret yoğunluğunu göstermektedir. Endeksin 1'in üzerinde değer alması ihracat yapan tarafin ihracatın yapıldığı ülkenin dünya ticaretindeki payı esas alındığında, iki taraf arasında gerçekleşmesi gerekenden fazla ticaret gerçekleştiği şeklinde yorumlanabilir.

Çalışmada elde edilen veriler Dünya Ticaret Örgütü (WTO), Türkiye Cumhuriyeti Ticaret Bakanlığı ve Türkiye İhracatçılar Meclisi'nden (TiM) elde edilmiştir. Elde edilen veriler ArcGiS10.3 programı ile harita üzerinde işlenerek mekânsal dağılım değerleri gösterilmiştir.

\section{Analiz ve Bulgular}

Gaziantep sosyo-ekonomik gelişimi ile orantlı olarak imalat sanayi, kurulu güç kapasitesi ve istihdamın sektörel dağılımı bakımından bölgesi içinde ayrışmakta (Aktaş \& Çatalbaş, 2011) ve bölge sanayisindeki güçlü etkisini öteden beri sürdürmektedir (Mutluer, 2003). Türkiye'nin nüfus olarak dokuzuncu büyük ili olan Gaziantep, ihracatta ise altıncı sırada yer almaktadır ve yerel sanayileşme odaklarının öncü kentlerindendir (Sandal \& Şen, 2016; Ayık \& Enterili, 2020). Bölge içinde ekonomik göstergelerle rakipsiz bir pozisyona sahip olan kent, Türkiye için de önemli bir ihraç üssü olmaktadır. Kent, sanayi ve ticaret geçmişinden gelen gücü, günümüzde ihracat performansına da yansıtmıştır. Nitekim 2002-2019 yılları arası Türkiye ihracat $\% 80,1$ artş gösterirken, aynı dönemde Gaziantep'in ihracat $\% 91,7$ ile ortalamanın üstünde bir artış göstermiş ve hemen her yıl artış oranı Türkiye ortalamasından daha fazla olmuştur (Şekil 1).

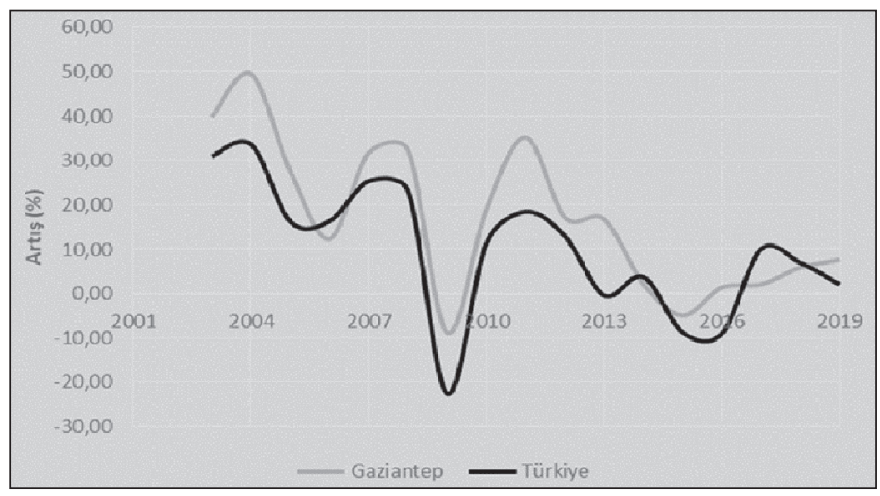

Şekil 1. Türkiye ve Gaziantep ihracatının yüzdelik değişimi (2002-2019). Figure 1. Percentage change of Turkey and Gaziantep exports (2002-2019). Kaynak: TÜiK verilerinden yararlanılarak yazar tarafindan hazırlanmıştır.

2002 yılında Türkiye toplam ihracatının \%1,76'sını gerçekleştiren kent, bu oranı 2020 yılında \%5,07'ye çıkarmış, oransal olarak \%188'lik bir artış gerçekleştirmiştir. Aynı dönemde ìs- 
Tablo 3. Gaziantep'ten en fazla ihracatın yapıldığı ilk beş ülke (2010-2019).

Table 3. Top five countries with the most exports from Gaziantep (2010-2019).

\begin{tabular}{|c|c|c|c|c|c|c|c|c|c|}
\hline 2010 & 2011 & 2012 & 2013 & 2014 & 2015 & 2016 & 2017 & 2018 & 2019 \\
\hline Irak & Irak & Irak & Irak & Irak & Irak & Irak & Irak & Irak & Irak \\
\hline S.Arabistan & S.Arabistan & S.Arabistan & S.Arabistan & Suriye & Suriye & $A B D$ & $A B D$ & $A B D$ & $A B D$ \\
\hline Almanya & Almanya & Almanya & Suriye & $A B D$ & $A B D$ & S.Arabistan & S.Arabistan & S.Arabistan & S.Arabistan \\
\hline Suriye & B.Krallık & B.Krallık & $A B D$ & Libya & İran & İran & İran & İtalya & B. Krallık \\
\hline
\end{tabular}

Kaynak: TiM verilerinden faydalanılarak yazar tarafindan oluşturulmuştur.

nı içinde düşmesinin, yani coğrafi çeşitliliği artırma anlamında olumludur. Aynı durum Gaziantep'in yıllar içinde en fazla ihracat yaptığı ilk beş ülke (Tablo 3 ) için de geçerlidir.

2010 yılında Gaziantep'in ihracatında ilk beş sırada yer alan ülkelerin Gaziantep'in toplam ihracatındaki ortalama payı \%10,07 iken 2019 yılında \%8,70’e düşmüştür (Şekil 4).



Şekil 4. Gaziantep'ten en yüksek ihracatın yapıldığı ilk beş ülkenin Gaziantep ilinin toplam ihracatna oranları (2009-2019).

Figure 4. The ratio of the top five countries with the highest exports from Gaziantep to the total exports of Gaziantep province (2009-2019).

Kaynak: TiM verilerinden faydalanılarak yazar tarafindan hesaplanmıştır.

Bu durum ihracatın toplamında artış şartını taşıdığı için coğrafi çeşitliliğin de arttı̆ının anlamlı bir göstergesidir. Aynı zamanda toplam ihracatın artışı ile beraber gerçekleştiği için, ihracatın daha geniş bir tabana yayıldığını yani coğrafi çeşitliliğin arttığını göstermektedir.

Coğrafi çeşitliliğin artmasının, yerel ekonomilerdeki ihracatçı firmalar ve bağlantlı ağları üzerinde de olumlu yönde etkileri görülmektedir. Nitekim ihracatçı firmalar, dış ticarette ürün ve coğrafi çeşitlilik anlamında ne kadar uzmanlaşırlarsa o nispette sermayesi büyük, üretim kapasitesi yüksek ve daha verimli olmaktadırlar (Dalgıç \& Fazlıŏ̆lu, 2015). İhracatçı firmalar, coğrafi çeşitliliğini artırdıkça uzmanlaşmayı, beraberinde gelen sermaye artışlarını ve beşeri sermaye odaklı yaratıcı sınıf da kendilerine çekerek, yaratıc kentsel gelişime de katkı sunmaktadırlar.

İhracat artışı ile gelen coğrafi çeşitlendirme artı̧sının arkasında, bir coğrafi bölgede/pazarda büyüme ile beraberinde gelen rekabet artş̧ı ve uzmanlaşmanın firmaları yeni pazar arayışlarına yönlendirmesi yatmaktadır. Belirli sektörlerin yerel veya bölgesel olarak mekânsal kümelenmesi firmalara maliyet, ulaşım, uzmanlaşmış işgücü ve beşeri sermaye gibi avantajlar sağlamasının yanında, coğrafi çeşitlendirme noktasında da büyük destek sağlamaktadır. Özellikle makine halısı, iplik ve genel olarak endüstriyel tekstiller üretiminde kümelenme oluşturan ve rekabet avantajı sağlayan kentte, firmalar ihracat pazarlarında daha agresif büyüme stratejisi sürdürmekte, bu durum da yeni ihracat pazarları arayışını hızlandırmaktadır.
Teknolojik imkânların artması ve ulaşımda yaşanan hızlı gelişmeler vasıtasıyla yeni pazarlara giriş imkânlarının artması gibi nedenler de bu sebeplere eklenebilir (Çınar \& Göksel, 2010). Gaziantep'te uzmanlaşmanın gerçekleştiği teknik tekstiller sektöründe "çoğu firma doğrudan ihracat yapmakta, bu da aracı sayısının azalmasına yol açmaktadır. Bu durum maliyetlerin azalmasına ve rekabet gücünün artmasına olumlu bir katkı sunmaktadır" (Akardeniz \& Kıraç, 2015: 467).

Gaziantep'in ihracat yaptığı ülkeler içerisinde, o ülkenin ithalat içerisinde aldığı paylara yani TII değerlerine bakıldığında ise yüksek değere sahip ülkelerin coğrafi yakınlık ekseninde üç temel bloğa yayıldığı görülmektedir. Bunlar: Ortadoğu, Afrika ve Avrupa'dır (Şekil 5). En yüksek TII değerine sahip olan ülke Suriye'dir. Suriye ile olan ihracatta TII endeksinin beklenenden yüksek bir ticarete işaret eden 1 değerinin yaklaşık 2,5 kat daha yüksek bir değer aldığı göze çarpmaktadır.

İki binli yılların ilk on yılında, Türkiye-Suriye ilişkileri birçok alanda olumlu bir seyir izlemiştir (Benek, 2016), ancak 2011 yılında Suriye'de başlayan iç savaş ve sonrasında meydana gelen gelişmeler Gaziantep-Suriye dış ticaretinde dalgalı bir manzarayı da beraberinde getirmiştir. İç savaşın başladığı ilk yıllarda (2011 ile 2012 yılları arasında) ihracat miktarı \%54 düşmüştür. Suriye ile olan ticaretin düşmesi yalnızca Suriye pazarını etkilemekle kalmamış, Ortadoğu ve tüm Kuzey Afrika pazarlarını da etkilemiştir. Savaş öncesi dönemde birçok Ortadoğu ülkesine (Ürdün, Lübnan, Suudi Arabistan gibi) ürünler Suriye üzerinden transfer edilir, böylece hızlı ve düşük maliyetlerle teslimatlar gerçekleştirilirken, savaş sonrası ürünler bu ülkelere deniz yolu ile gönderilmiş bu durumda maliyetleri artırıp, rekabetçiliği düşürerek satışları azaltmıştır (İzmen vd., 2015). Ortadoğu'da oluşan bu kırılgan ortam, özellikle Suriye'de yaşanan savaş, Suriye'ye ve daha geniş kapsamda Ortadoğu ülkelerine yapılan ihracatı olumsuz yönde etkilemiştir (Tezel, 2018).

Son yıllarda Suriye'nin kuzeyinde oluşturulan güvenli bölgenin yeniden inşasında etkin rol oynayan Türkiye, bu alandaki en büyük ekonomik aktör olmuştur. Bu durum, Suriye'nin düşen ithalat ile birlikte değerlendirildiğinde TII değerinde Türkiye lehine bir durumu ortaya çıkarmıştır. TII değerinin yüksek olmasında hem Suriye'nin toplam ithalatının düşmesinin hem de Türkiye'nin toplam ihracatının kuzeyde oluşturulan güvenli bölgeye yapılan ihracat sayesinde ortalamaların üzerinde bir artı̧ göstermiş olmasından kaynaklanmaktadır.

İç savaş öncesi dönemde ithalat odaklı bir dış ticaret politikası yürüten Suriye, muhtemelen savaş sonrası dönemde de aynı politikaları uygulaması tercihten ziyade bir zorunluluk olacaktır. Savaş öncesi dönemde dahi imalat sektöründe çeşitlilik sağlanmasına rağmen, birçok ürün gelişen piyasaların benzer ihraç ürünlerinin kalitesiyle rekabet edememekteydi (ITKIB, 2010). 


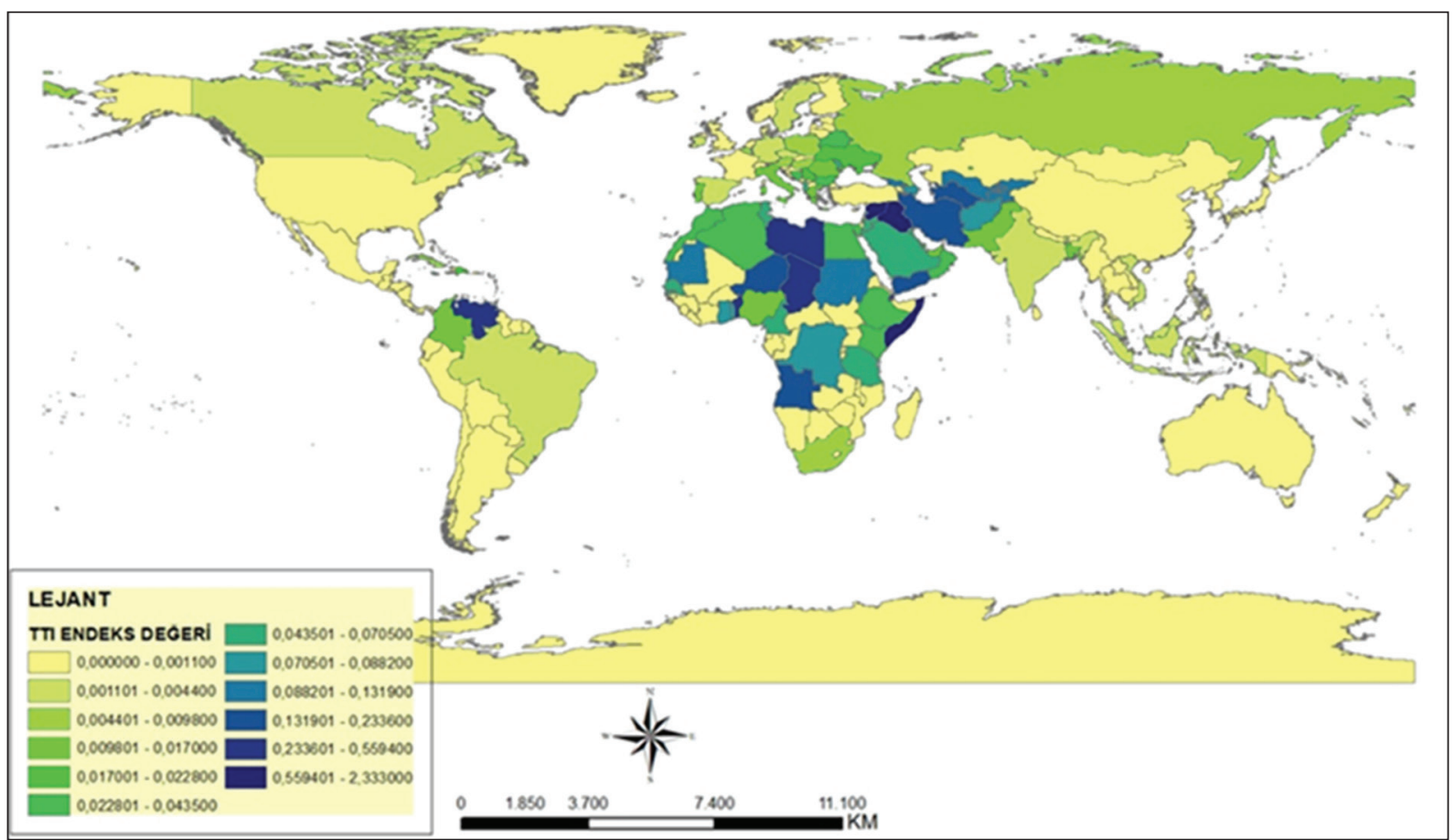

Şekil 5. Gaziantep ilinin ihracatında ticaret yoğunlaşma endeksi değerleri (2019).

Figure 5. Gaziantep province trade Concentration Index values (2019).

Kaynak: TiM verilerinden yararlanılarak yazar tarafindan çizilmiştir.

Önümüzdeki dönemde Suriye'de yaşanan mevcut sorunların aşılması durumunda ülke, ekonomisini ve ithalatını gerek ülkenin yeniden inşa sürecinde gerekse sonrasında artırması kuvvetle muhtemeldir. Bunun yanında Türkiye'nin Suriye'nin yeniden inşa sürecinde, coğrafi avantajlarını ön planda tutarak, dünyada en fazla Suriyeli nüfusu barındırması ve bu göçmenlerin geri dönüşünün sağlanması ekseninde süreçte ödediği maddi manevi bedellerin doğal bir dönüşü olarak önemli bir yer edinecektir. Tüm bu noktaların yanı sıra uluslararası ticaret, karayolu geçişi, güvenlik ve insani konular açısından da Türkiye'nin Suriye'yi yeniden inşa eden ülkeler listesinin başında olması gerektiğini ortaya koymaktadır (ATO, 2019). Gaziantep bu süreçte açılacak yeni yatırım sahalarında coğrafi, kültürel, sosyal bağlarının getirdiği avantajlarını ve sahip olduğu ihracatçı yapısını da önemli bir etken olarak kullanmalıdır.

TII değerlerinde Suriye'yi Irak ve Somali takip etmektedir. Ortadoğu ve Afrika ülkelerinin ağırlığı göze çarpmakla birlikte endekste ilk ülke ile diğer ülkeler arasındaki farkın fazlalığı dikkat çekmektedir. Gerek coğrafi yakınlık avantajları, gerekse kültürel ve tarihi bir ortak geçmişe sahip olmanın getirdiği faydalar, Ortadoğu ülkelerinin TII değerlerinin yüksek çıkmasında önemli bir etkendir. Ayrıca söz konusu ülkelerin ithalat rakamlarının çok yüksek olmaması da bu pazarlarda yoğunlaşmanın yani TIl endeks değerinin yüksek olmasının bir diğer sebebidir. Ortadoğu pazarı herhangi bir ihracat bölgesi olarak ele alınmamalıdır. Gaziantep'te özellikle Ortadoğu ile yapılan ihracat bölgedeki ticaretin yanı sıra imalatın teknik ve sosyal koşullarını da belirlemektedir (Akdemir \& Öngel, 2017: 63). Bir anlamda Gaziantep ile Ortadoğu arasında, karşılıklı bir ürün arzı-talebi döngüsü ötesinde imalat yapısını ve teknolojisini hatta işçi yeterliliklerini de etkileyen bir yapı oluşmuştur. Gerek bu ülkelerin istikrarı, gerekse Türkiye'nin ekonomik büyüme hızı, en büyük fayda değerini yine Türkiye ve dolayısıyla Gaziantep lehine gösterecektir. Bu bölgenin sahip olduğu ekonomik ve beşeri zenginlikler somut kazançlara dönüştürülebilirse, bölge içi aktörler arasında kayda değer bir ticari ilişkiler zinciri ortaya çıkarabilir (Kula \& Aslan, 2008).

Afrika Boynuzu'nun en stratejik ülkesi olan Somali ile ilişkiler, On altıncı yüzyılın ilk yarısında başlamıştır. Türkiye'nin Afrika'ya açılan bir kapısı olarak (SDE, 2020) Somali ithalatında Türkiye, Çin ve Hindistan'dan sonra üçüncü sırada gelmektedir. Somali ile 2019 yılında ikili ticaret hacmimiz 250 milyon dolar olarak gerçekleşmiştir, bunun 6 milyon doları ithalat, 244 milyon doları ihracattır (MFA, 2020). Gaziantep, Somali'ye yapılan toplam ihracatı 94,8 milyon dolarını yani yaklaşık olarak \%39'unu tek başına gerçekleştirmektedir. Somali pazarında yüksek TII değerinin olması, Türkiye ile Somali arasında tarihsel bağların varlığı ve günümüz Afrika açılımında stratejik bir ortak olarak görmesinin bir sonucudur. Bu bağlamda Türkiye'nin Somali'deki Askeri Üssü, Somalili öğrencilerin Türkiye Bursları, Somali'nin vadesi geçmiş IMF borcunun ödenmesi gibi başlıklar bu stratejik yaklaşımın örnekleridir.

“Türkiye'nin sürdürülebilir bir ihracat altyapısının oluşturulması ve özellikle ihracatta bölgesel bağımlılığın önüne geçilmesi isteği ihracat pazarlarının çeşitlendirilmesini gerekli kılmış; bu durum da Afrika kıtası özelinde ilk karşılığını 1998 yılında hazırIanan "Afrika'ya Açılım Eylem Planı'nda göstermiştir" (Sümer, 2012: 7). Somali, Benin, Cibuti, Libya, Çad, Nijer gibi büyük bir potansiyel taşıyan Afrika ülkelerinde yoğunlaşma olması aynı zamanda ulusal olarak Afrika pazarında genişleme stratejisi ile de uyumlu gözükmektedir. Bu bağlamda, Türk işadamlarına yeni pazar alanlarının oluşturulması ve Türklerin Afrika ülkelerinde daha aktif ekonomik faaliyetler içerisine girmeleri için olanak sağlamak ve bu konuda her türlü siyasi desteğin verilmesi büyük önem arz etmektedir (Sıradağ, 2016). Ancak gerek Ortadoğu gerek Afrika pazarları iç savaş ve terör riskleri sebebiyle kolay yatırım yapılabilecek pazarlar değildir. 
Türkiye'nin dış ticaretinin en büyük ticari partneri $A B$ ülkeleridir (Karakaş, 2017; Kotil, 2019). Bununla birlikte yüksek bir ithalat oranına sahip İtalya ve Birleşik Kralık gibi iki Avrupa ülkesinin endekste yer alması Gaziantep ihracat için önemli bir parametredir. Özellikle Avrupa pazarlarında hem coğrafi çeşitliliği hem de ticaret yoğunlaşma değerlerini artırmak diğer pazarlara nazaran daha stratejik bir anlam da taşımaktadır. Bu ülkelerin yüksek dış ticaret hacmine sahip olmaları, bu pazarlara yapılacak ihracatın hacmi ve istikrarı göz önüne alındığında diğer pazarlara nazaran daha önemli kılmaktadır. Ayrıca bu durum Türkiye'nin uzun yıllar boyunca hedef koyduğu $A B^{\prime}$ ye üyelik projeksiyonuna da ülkemiz lehine pozitif bir katkı sağlayacaktır.

\section{Tartışma ve Sonuç}

İhracat ve ekonomik büyüme üzerine yapılan ve oldukça büyük bir sayıya ulaşan literatürde coğrafi çeşitlilik değişkeninin kent odaklı çok fazla yer almadığı anlaşılmıştır. Mevcut çalışmaların ülke veya ülkeler grubu eksenin de yapıldığı görülmektedir. Kent odaklı coğrafi çeşitlilik çalışmalarının ise literatürde neredeyse hiç yer almadığı görülmektedir. Oysa coğrafi çeşitliliği artırma sanayi coğrafyası çalışmalarında birçok beşeri-ekonomik olay ve olguları değerlendirmede önemli bir başlık olarak değerlendirilmelidir. Bu noktada çalışmanın coğrafi çeşitlilik tartsşmaları eşliğinde kent odaklı sanayi coğrafyası çalışmaları için önemli bir boşluğu doldurma potansiyeli söz konusudur.

Son yıllarda istikrarlı bir ihracat artışı hedefleyen ve bu yolda önemli aşamalar kaydeden Türkiye, ihracat odaklı büyüme politikasını devam ettirmektedir. Soğuk savaş sonrası ortaya çıkan; yeni güvenlik konseptleri çerçevesinde sürekli yeni sıcak çatışma cephelerinin açılması pek çok ülkeyi ve doğal olarak Türkiye'yi de ihracat odaklı büyüme politikalarında, coğrafi çeşitliliği artırma çabalarına itmektedir.

Dünya ile daha fazla bütünleşerek bölgesel bir güç olma doğrultusunda ekonomik hedefler koyan Türkiye, bu hedeflere ulaşmanın en önemli parametrelerinden birisi olarak kuşkusuz gerçekleştirdiği ihracatın niceliği kadar niteliğini de (ürün kalitesi, ürün içeriği ve coğrafi çeşitliliği) görmektedir. Nitekim bu doğrultuda On Birinci Kalkınma Planı'nda daha spesifik pazar ve ürün merkezli bir yaklaşımla, ihracatçı firmaların global değer zincirlerinin yüksek katma değer ortaya koyan platformlarına bağlanmasını destekleyen, sürdürülebilir bir ihracat artışını hedefleyen ihracat Ana Planı hazırlanarak uygulamaya konulması amaç olarak yer almıştır (SBB, 2020: 36).

Günümüzde ihracatn niceliksel büyüklüğünün bilinmesi kadar; ihracatın hangi pazarlara yapıldığının yani coğrafi çeşitliliğinin bilinmesi de büyük önem arz etmektedir. Gaziantep, Türkiye'nin önemli bir ihracat kapısıdır. Türkiye'nin kalkınmada geri kalmış bir bölgesinde yer almasına rağmen göstermiş olduğu performansın araştırılması gerekmektedir. On altıncı yüzyıldan itibaren hac yolunda önemli bir lojistik merkezi olması ile başlayan ticari canlılığını Cumhuriyetin ilanından itibaren sanayi odaklı bir gelişime dönüştürmeyi başarmıştır. Yirminci yüzyılın ortalarından itibaren kurulan OSB ve dönemin sonlarından itibaren başlayan ihracat odaklı çabalar meyvelerini vermiş, bölge içinden ve kendi kırsalından aldığı göçlerle kent önemli bir sermeye çekim merkezi haline gelmiştir. Çok fazla devlet desteği almadan kendi ekonomi dinamikleri ve tecrü- beleri ile önemli bir ihracatçı yapıya bürünmüştür. Bu durum sermayenin yalnızca bölge içi değil bölge dışı hatta Suriye ve Irak'tan da sermaye akışının artarak devam etmesini sağlamıştr. Böylece Gaziantep sadece bölgesindeki illerden pozitif olarak ayrıştırmakla kalmamış aynı zamanda ülke içinde de parlak bir ekonomik manzaraya kavuşmuştur.

2010-2019 yılları arası Türkiye'nin ihracat performansından daha iyi bir performans sergileyen Gaziantep'te ihracat yapılan ülke çeşitliliği anlamlı bir şekilde artış eğilimindedir. Bu duruma sebep olarak il genelinde uzmanlaşma ve rekabet artışı neticesinde firmaların daha proaktif davranış stratejileri ile yeni pazarlar aramaları ile kentte oluşan çok aktörlü bir ihracat ağı gösterilebilir. Özellikle makine halısı ve endüstriyel tekstiller alanında önemli bir kümelenme mekanı olan kent, bu durumun verdiği rekabet avantajlarını en iyi şekilde değerlendirmiştir. Bu endüstriyel kümelenme beraberinde sermayeyi, kalifiye işgücünü ve beşeri sermayeyi kendisine çekmiş, böylece ülkenin en dezavantajlı bölgesinde yer alan Gaziantep, büyük bir ihracatçı kent halini almıştır.

Çalışmada, söz konusu dönemde her yıl en fazla ihracatın yapıldığı ülke Irak olmasına rağmen, ilin toplam ihracatından aldığı pay yaklaşık olarak yarı yarıya düşmüştür. Aynı düşüş eğilimi en yüksek ihracatın yapıldığı ilk beş ülke için de geçerlidir. Coğrafi çeşitlilikte yakalanan bu ivmenin sürdürülebilmesi, toplam ihracat miktarının artışı ve ürün niteliklerinin geliştirilmesi ile çok daha sağlıklı bir gelişimi destekleyecektir. Coğrafi avantajlarını, tarihi ve kültürel bağlarını etkili bir şekilde kullanarak Ortadoğu ülkeleri ile önemli bir ekonomik ilişki geliştiren Gaziantep; Afrika, AB ve Orta Asya ülkelerini de ihracat portföyüne ekleyerek coğrafi çeşitliliğini artırma yönünde adımlar atmaktadır.

Düşük verimlilik, birkaç sektörde üretim yoğunlaşması, ihracatta coğrafi çeşitliliğin düşük seyretmesi, zayıf gelirli ithalat pazarlarında yoğunlaşma, stratejik çatş̧ma alanlarında iş yapma gibi riskler gelecek için olumsuz senaryolar olarak görülmektedir. Kentin demografik göstergeleri, göç alma noktasında büyük bir artı̧ın olacağını öngörmese de göçün devam edeceğini, kentsel büyümenin hızlanacağını öngörmektedir. $\mathrm{Bu}$ durum kentte yeni istihdam alanları oluşturulması bağlamında, kentin ihracat artışı üzerinde büyük bir baskı oluşturacağını göstermektedir.

Gaziantep yeterli düzeyde bilgi ve birikim sermayesinin gücüyle elde ettiği ihracat kapasitesini, en rasyonel bir şekilde tanımlamalı ve bu tanımlama üzerinden bir yol haritası çizmelidir. Birden fazla yerel aktörün, ulusal üst bağlantıları ile bir ilişkiler ağı oluşturularak bu ağın sürekli bir öğrenme süreci ile beslenmesi gereklidir. Kentin beşeri kaynaklarının ve insan sermayesinin fiziki coğrafyası ile uyumlu bir şekilde büyümesi önemli bir noktadır. Gelir dağılımını mümkün olan en optimum düzeye çekerek gerçekleştirilecek bir dönüşümün yerel, bölgesel ve ulusal kalkınma için eşsiz firsatlar ve örnekler sunması mümkün görünmektedir. Endüstri 4.0 uyumlu, akıllı kentler, öğrenen kentler, yaratıcı kentler ile bağlantılı ihracatta coğrafi çeşitlilik sağlanmalıdır.

Gaziantep ve diğer ihracat miktarı yüksek, ülke için kritik öneme sahip kentlerin sürdürülebilir bir büyüme süreci birçok faktöre bağlı olarak değişmektedir. Bu faktörlerden birisi de ileri 
teknoloji ile üretilen katma değeri yüksek ürünlerin ihracıdır. Bu ürünlerin çeşitliliğinin ve niteliğinin artırılması coğrafi çeşitliliği de besleyecek unsurlardan biridir. Her anlamda ürün çeşitliliği, ürünün niteliği önemli olmakla birlikte ihracat yapılan ülke sayısının nitelikli olarak artırılması ihracatçı mekânın; dünyada aşırı kırılgan ve birbirine geçmiş ekonomik, siyasi, sosyal riskleri en az düzeye indirmek için kaçınılmaz olarak başvurmaları gereken bir yoldur. Son olarak, sektörel ve ürün bazlı değerlendirmelerin yanında ihracatın çizmiş olduğu coğrafi çerçeve ve bu çerçevenin sınırları, sınırlılıkları ve boyutlarının da bilinmesi ve her türlü gelecek projeksiyonunun bu bütünlük içinde ele alınması ihmal edilmemesi gereken bir husus olarak karşımızda durmaktadır.

\section{Kaynakça}

Acaravcı, A. \& Kargı, G. (2015). Türkiye'de ihracatın çeşitlendirilmesi ve ekonomik büyüme. Uluslararası Ekonomi ve Yenilik Dergisi, 1(1),1-16. https://doi.org/10. 20979/ueyd.182891

Aditya, A. \& Acharyya, R. (2011). Export diversification, composition, and economic growth: evidence from cross-country analysis. The Journal of International Trade \& Economic Development, 22 (7), 959-992. https://doi.org/10.1080/09638199.2011.619009

Agosin, M. R. (2009). Export diversification and growth in emerging economies, CEPAL Review, 97, 115-131. http://hdl.handle. net/11362/11322

Agosin, M. R., Alvarez, R. \& Bravo-Ortega, C. (2012). Determinants of export diversification around the world: 1962-2000. The World Economy, 35(3), 295-315. https://doi.org/10.1111/i.14679701.2011.01395.x

Akal, M. (2008). Ortadoğu sınır ülkeleriyle dış ticaret yoğunlaşması ve yapısal değişim. Gaziantep Üniversitesi Sosyal Bilimler Dergisi, 7(2), 271-296. https://dergipark.org.tr/en/pub/jss/issue/24248/257118?publisher=gantep

Akar, G. \& Ay, A. (2019). Ürün ve ülke açısından ihracat çeşitlendirmesi: Türkiye üzerine bir değerlendirme. Gümüşhane Üniversitesi Sosyal Bilimler Enstitüsü Elektronik Dergisi, 10(1),116-127. https//dergipark.org.tr/en/pub/gumus/issue/44146/46099

Akardeniz, E. \& Kıraç, F. (2015). Rekabet ve yoğunlaşma düzeyinin ölçülmesi; Gaziantep teknik tekstiller piyasası. The Journal of Academic Social Sciences 10(10), 451-472. http://dx.doi. org/10.16992/ASOS.523

Akdemir, N. \& Öngel, S. F. (2017). Gaziantep'te göç ve yerellik üzerinden birikim dinamikleri. Emek Araştırma Dergisi (GEAD) 8, (11), 55-74. http://www.emekarastirma.org/uploads/dergi/2910.pdf

Aktaş, M. T. \& Çatalbaş, N. (2011). Güneydoğu Anadolu Bölgesi'nin kalkınma ve ihracat ilişkisi üzerine bir inceleme. Marmara Üniversitesi i.I.B.F. Dergisi, Cilt XXXI, (II), 61-90. https://dergipark. org.tr/en/pub/muiibd/issue/498/4447

Aldan, A., Aydın, M. F., Çulha, O. Y., Sunel, E. \& Taşkın, T. (2012). ihracatta bölgesel ve sektörel çeşitlenme. Ekonomi Notları, 18. https://ideas.repec.Org/p/tcb/econot/1218.html

Al-Marhubi, F. (2000). Export diversification and growth: an empirical investigation. Applied Economics Letters, 7(9), 559-562. https:// doi.org/10.1080/13504850050059005

Amurgo-Pacheco, A. \& Pierola, M. D. (2008). Patterns of export diversification in developing countries: intensive and extensive margins. Policy Research Working Paper; No. 4473. World Bank, Washington, DC.
Arınç, K. (2011). Doğal, iktisadi, sosyal ve siyasal yönleriyle Türkiye'nin iç Bölgeleri. Eser Ofset Baskı Matbaacılık, Erzurum. ISBN 978-605-61910-0-8

ATONET (Ankara Ticaret Odası) (2021, Ocak 19) https://www.atonet. org.tr/IcerikDetay/11693 baran-suriye?nin-yeniden-insasi-calistayina-katildi

Avcı, S. (2000). Türkiye'nin ekonomi politikaları ve coğrafi sonuçları. Coğrafya Dergisi Sayı:8, 29-70. https://dergipark.org.tr/tr/pub/ iucografya/issue/25057/264547

Ayık, U \& Enterili, Z. (2020). Değişen kent politikaları ve kentsel dönüşüm: Gaziantep Nuripazarbaşı Mahallesi örneği. International Journal of Geography and Geography Education, 41, 221-244. https://doi.org/10.32003/igge.649700

Azgün, S. \& Takım, A. (2016). Türkiye'nin dış ticaretinde mal ve ülke yoğunlaşması. 2. Uluslararası Kafkasya-Orta Asya Dış Ticaret ve Lojistik Kongresi: 275-282. Erzurum, Turkey.

Benek, S. (2016). Türkiye-Suriye ilişkilerinin sosyal coğrafya açısından tarihsel arka planı. Gaziantep University Journal of Social Sciences, 15 (1), 171-192. https://doi.org/10.21547/iss.256743

Boehe, D. \& Jimenez, A. (2018). Does the sequencing of related and unrelated export diversification matter? evidence from Colombian exporters. International Business Review, 27, (6), 1141-1149. https://doi.org/10.1016/i.ibusrev.2018.04.0 05

Brenton, P., Newfarmer, R. \& Walkenhorst, P. (2009). Avenues for export diversification: issues for low-income countries. MPRA, Commission on Growth and Development Working Paper, 47. Munich: MPRA.

Brown, A. J. (1949). Applied Economics: Aspects of the World Economy in War and Peace. London.

Coe, N. M., Kelly P. F. \& Yeung H. W.C (2007). Economic geography: A contemporary introduction. Blackwell Publishing. ISBN 978-14051-3215-2

Cos, P., Colom, A. \& Cabases A. (2019). Geographic export diversification: determinants and their link with export performance. International Business Theory and Application 61:397-411. https://doi.org/10.1002/tie.21991

Çınar, Y. \& Göksel, T. (2010). İhracatta bölgesel çeşitlendirme ve istikrar. Ankara Üniversitesi SBF Dergisi, 65 (02), 29-57. https://doi. org/10.1501/SBFder 0000002169

Dalgıç, B. \& Fazlıoğlu, B. (2015). Dış ticarette ürün/ülke çeşitliliği ve firma performansı: Türkiye örneği. Sosyoekonomi, Vol. 23 (26), 7-23. https://dergipark.org.tr/en/pub/sosyoekonomi/issue/21086/227041

Değer, M. K. (2010). İhracatta ürün çeşitliliği ve ekonomik büyüme: Türkiye deneyimi (1980- 2006). Atatürk Üniversitesi Iktisadi ve Idari Bilimler Dergisi, 24 (2), 259-287. https://dergipark.org.tr/ en/pub/atauniiibd/issue/2699/35591

Değer, M. K. \& Genç, M. C. (2010). İhracatta ülke çeşitliliğinin toplam ihracat ve hâsıla üzerine etkisi: Türkiye ekonomisi üzerine eş-bütünleşme ve nedensellik testleri (1980-2007). Akdeniz iiBF Dergisi, 10 (20), 66-85. https://dergipark.org.tr/en/pub/auiibfd/ issue/32323/359209

Demir, M. A. (2020). Türkiye ile seçilmiş Ortadoğu ülkeleri arasındaki ticaret yoğunluğunun analizi. Nazilli iktisadi ve Idari Bilimler Fakültesi Dergisi, Volume 1, (1), 1-14. https://dergipark.org.tr/en/ pub/niibfd/issue/55259/745791

Didier, L. (2017). South-south trade and geographical diversification of intra-SSA trade: evidence from BRICS. African Development Review, Vol. 29, No. 2, 139-154. https://doi.org/10.1111/14678268.12246 
Dinçer, H. (2019). Kurtuluştan sonra Gaziantep (Türkiye'nin sıhhi ve içtimai coğrafyası: Gazi Ayıntâb vilayeti). Çağdaş Türkiye Tarihi Araştırmaları Dergisi XIX/38, 75-97. https://dergipark.org.tr/en/ pub/cttad/issue/50526/657202

Doğan, M. (2021). Ekonomik coğrafya (4.Baskı), Doğan, M. \& Doğan-Sertkaya, Ö. (Ed.), Beşeri ve Ekonomik Coğrafya: 159-195. İstanbul: Pegem Akademi.

Doğan, S. \& Soyyiğit Kaya, S. (2011). Gümrük Birliği sonrasında (1996-2009) Türkiye'nin Avrupa Birliği ile dış ticaretinin ülke ve fasıl bazlı yoğunlaşma analizi. İstanbul Üniversitesi iktisat Fakültesi Ekonometri ve Istatistik Dergisi, 14, 1-18. https://dergipark. org.tr/en/pub/iuekois/issue/8981/112033

Doğanay, H., Özdemir, Ü. \& Şahin, İ. F. (2020). Genel beşeri ve ekonomik coğrafya. Pegem Akademi (11. Baskı), İstanbul. ISBN 978605-364-119-3

Edmonds, C. \& Li, Y. (2010). A new perspective on china trade growth: application of a new index of bilateral trade intensity. Honolulu: University of Hawaii at Manoa, Department of Economics, Working Papers, 201025.

Erkan, B. (2012). Ülkelerin karşılaştırmalı ihracat performanslarının açıklanmış karşılaştırmalı üstünlük katsayılarıyla belirlenmesi: Türkiye-Suriye örneği. ZKÜ Sosyal Bilimler Dergisi,8,(15),195-218. https://dergipark.org.tr/en/pub/ijmeb/issue/54849/75108

Erkan, B. \& Sunay, Z. F. (2016). Türkiye'nin ihracatının yoğunlaşma perspektifinde analizi. Insan ve Toplum Bilimleri Araştırmaları Dergisi Cilt: 5,(7),1823-1842. https://doi.org/10.15869/itobiad.259266

Erlat, G. \& Akyüz O. (2001). Country concentration of Turkish exports and imports overtime. Economics Web Institutes, www.luc.edu/ orgs/meea/volume3/gerlat.pdf

Herfindahl, O. (1950). Concentration in the steel industry, Columbia University Ph. D. thesis-New York.

Herzer, D. \& Lehnmann D, F. N. (2006). What does export diversification do for growth? Aneconometricanalysis, Applied Economics, 38(15), 1825-1838. https://doi.org/10.1080/00036840500426983

Hesse, H. (2009). Breaking into new markets emerging lessons for export diversification. In R. Newfarmer, W. Shaw \& P. Walkenhorst (Eds.), Export Diversification and Economic Growth (pp. 55-81). World Bank, Washington DC.290p

Hirschman, A. (1945). National power and the structure of foreign trade. University of California Press, 155-62.

ITKIB (İstanbul Tekstil ve Konfeksiyon İhracatçı Birlikleri) (2021, Şubat 12). http://www.itkib.org.tr.Suriye Ülke Raporu 2010.pdf

İzmen, Ü., Daş, Z. B. \& Özbal, Y. (2015). Bölgesel kalkınma dinamikleri: ihracat ve sanayi kenti Gaziantep - Rekabet Gücü Analizi ve 2023 senaryoları. İstanbul. Promice Dijital Matbaacılık. ISBN: 978-605-64879-5-8

Karakaş, A. (2017). İthalata dayalı ihracatın riskli yapısı: dış ticarette sürdürülebilirliğin Türkiye için analizi. Kırıkkale Üniversitesi Sosyal Bilimler Dergisi, 7 (2), 261-278. https://dergipark.org.tr/en/ pub/kusbd/issue/30549/296087

Kaplan, H. \& Tur, F. (2017). Türkiye'de ihracatın sektör ve pazar çeşitliliği çerçevesinde yaşadığı yapısal dönüşüm. Ege Akademik Bakış, Cilt 17(1), 59-74. https://doi.org 10.21121/eab.2017123468

Koçal, A. V. (2013). Kuzey Irak'la sınır ticaretinin Güneydoğu Anadolu Bölgesi'ne sosyoekonomik etkileri bağlamında kentleşmenin ekonomi politiği. I. Türkiye Lisansüstü Çalışmaları Kongresi Bildiriler Kitabı, 29 Haziran-01 Temmuz 2012, Konya

Kojima, K. (1964). The pattern of international trade among advanced countries. Hitotsubashi Journal of Economics, Vol. 5 (1) : 16-36. https://www.jstor.org/stable/43295433
Kotil, E. (2019). Türkiye'nin Avrupa Birliği'ne ihracat: çekim modeli analizi. Ekonomik ve Sosyal Araştirmalar Dergisi, Cilt 15,(2), 167-175. https://dergipark.org.tr/en/pub//esad/issue/49561/604724

Kösekahyaoğlu, L. (2007). Türkiye dış ticaretinde ürün ve ülke bazında yoğunlaşma: 1980-2005 dönemi üzerine karşılaşttrmalı bir analiz. i.ü. Siyasal Bilgiler Fakültesi Dergisi No:36, 15-34. https:// dergipark.org.tr/en/pub/iusiyasal/issue/600/6047

Kunimoto, K. (1977). Typology of trade Intensity Indices. Hitotsubashi Journal of Economics, 17 (2), 15-32.

Kula, F. \& Aslan, A. (2008). Türkiye'nin Ortadoğu'da ekonomik geleceği: Türkiye'nin ihracat potansiyeline yönelik ampirik bir analiz. MPRA Paper 10688, University Library of Munich, Germany.

Lederman, D. \& Maloney W. F. (2009). Breaking into new markets emerging lessons for export diversification. In R. Newfarmer, W. Shaw \& P. Walkenhorst (Eds.), Trade structure and Growth. (pp. 39-55). World Bank, Washington DC. 290p.

MFA (Ministry of Foreign Affairs) (2021, Şubat 7). http://www.mfa. gov.tr/turkiye-somali-siyasi-iliskileri.tr.mfa

Mortan, K. \& Arolat, O. S. (2009). Gaziantep ekonomisine bakış. Heyamola Yayınları: İstanbul, 103s.

Mutluer, M. (2003). Türkiye'de yeni gelişen sanayi odakları: Denizli-Gaziantep-Çorum. Ege Coğrafya Dergisi, 12 (1). https://dergipark.org.tr/en/pub/ecd/issue/4882/66952

Orhan, A. \& Demir, S. (2019). Gelir dağııımı eşitsizliğinin ölçümünde gini katsayısı mı theil endeksi mi? II. International Conference on Empirical Economics and Social Science (ICEESS' 19) June 2021-22, 2019 / Bandırma - Turkey 1331-1345.

Özdemir, Ü., Kantürk Yiğit, G. \& Oral, M. (2016). Cumhuriyetten günümüze ekonomi politikaları bağlamında Türk dış ticaretinin gelişimi. Doğu Coğrafya Dergisi, 21 (35), 149-174. https://doi. org/10.17295/dcd.23130

Özlü-Yıldız, Z. (2017). Gaziantep'in 1923-1938 yılları arasında ekonomik ve bayındırık alanındaki faaliyetleri. Uluslararası Sosyal Araşttrmalar Dergisi Cilt: 10 (51), 330-342. http://dx.doi. org/10.17719/jisr.2017.1769

Öztürk, B. (2005). Türk Yatırım Fonu Sektörünün Rekabet Yapısı. Sermaye Piyasası Rekabet Kurulu Araştırma Dairesi. Araştırma Raporu.

Öztürk, ì., \& Anıl, í. (2017). Uluslararası coğrafî çeşitlendirme derecesi ile iç ve dış faktörlerin firma performansı ile etkileşimi: Bist'e kayıtlı işletmeler üzerinde bir araştırma (2009-2014). Akdeniz i.i.B.F. Dergisi (36), 47-70. https://doi.org/10.25294/auii$\underline{\text { bfd. } 357612}$

Sandal, E. K., \& Şen, Ö. (2016). The agglomerated ındustrıl sectors in Gaziantep and these sector's distribution in Turkey. Turkish Studies, Volume 11/8,313-334. http://dx.doi.org/10.7827/TurkishStudies.9612

Saray, M. O. (2019). D-8 ekonomileri, dış ticaret desenleri ve Türkiye için önemi: ihracat ve ithalat yoğunluğu endeksiyle bir değerlendirme. Curr Res Soc Sci, 5 (2), 171-188. https://doi. org/10.30613/curesosc.627642

SBB (Strateji ve Bütçe Başkanlığı) (2021, Şubat 6). https://www.sbb. gov.tr/wp-content/uploads/2019/07/OnbirinciKalkinmaPlani. pdf

SDE (Stratejik Düşünce Enstitüsü) (2021, Mart 9). https://www.sde. org.tr/search?Search=somali

Shepherd, B. (2010). Geographical diversification of developing country exports. World Development Volume 38,(9), 1217-1228. https://doi.org/10.1016/i.worlddev.2010.02.005 
Shepotylo, O. (2013). Export diversification across countries and products: do Eastern European (EE) and Commonwealth of Independent States (CIS) countries diversify enough? The Journal of International Trade \& Economic Development, Vol. 22, No. 4, 605-638. https://doi.org/10.1080/09638199.2011.577797

Sıradağ, A. (2016). Türkiye-Somali ilişkileri: sebepler, dinamikler ve meydan okumalar, Ortadoğu yıllığı 2016, (Edt. İnat, K. ve Ataman, M.) Kadim Yayınları, Ankara, 713s

Soyyiğit, S., \& Doğan, S. (2019). Türkiye'nin Avrupa Birliği ülkeleri ile dış ticaretinin yapısal analizi: artan rekabet mi yoksa yoğunlaşma mı? Yönetim ve Ekonomi Araştırmaları Dergisi, Cilt: 17 (3), 164-180. https://doi.org/10.11611/yead.545692

Sönmez, M. E. (2012). Yerleşme yeri seçimi ve alansal gelişimi açısından Gaziantep, Özserhat Yayıncılık, Malatya, 187s.

Söylemez, S. A., Arslan, G. E., Çakar, G. E., Kalaycıoğlu, S., \& Özgen, L. (2012). Gaziantep sanayisi ve dinamikleri, Discussion Paper, No. 2012/83, Turkish Economic Association.

Sümer, G. (2012). Kuzey Afrika pazar araşttrması, https://fka.gov.tr/ arastirma-raporlari-detayi-1463574266165

Taş, i. (2011). Türkiye'de ihracat çeşitlendirmesi ve büyüme ilişkisi. [Yüksek Lisans Tezi Gaziantep Üniversitesi Sosyal Bilimler Enstitüsü]

TEPAV (Türkiye Ekonomi Politikaları Araştırma Vakfi). (2021, Şubat 8) https://www.tepav.org.tr/upload/files/14757615571.pdf

Tezel, í. (2018). Gaziantep Serbest Bölgesinin Gaziantep dış ticaretine katkısı. Gaziantep Üniversitesi Ayıntâb Araştırmaları Dergisi, 1(1), 103-114. https://dergipark.org.t r/tr/pub/gunaad/ issue/41357/499825

TiM (Türkiye İhracatçılar Meclisi) (2021, Şubat 2). https://tim.org.tr/ tr/ihracat-rakamlari

Torlak, Ö., Kula, V., \& Özdemir, Ş. (2007). Türk işletmelerinin ihracat performansı belirleyicileri, Gazi Üniversitesi Iktisadi ve idari Bilimler Fakültesi Dergisi 9/1, 103 -114. https://dergipark.org.tr/ tr/pub/gaziuiibfd/issue/28333/301113

Tümertekin, E. \& Özgüç, N. (1997). Ekonomik coğrafya -küreselleşme ve kalkınma. Çantay Kitabevi.

Türkcan, K. (2014). Investigation the role of extensive margin, Intensive margin, price and quantity components on Turkey's export growth during 1998-2011. Turkish Economic Association Discussion Paper, 2014/2, February

Ulusoy, R., \& Turan, N. (2016). Gaziantep ekonomisinin Ortadoğu açısından önemi. Gazi Akademik Bakış, Cilt 9 (18), 141-165. https:// doi.org/10.19060/gav.320741

Ünsal, A., \& Sülkü, S. N. (2020). Bölgeler arası gelişmişlik düzeylerinin belirlenmesi ve karşılaştrılması: Türkiye örneği. Bilig Türk Dünyası Sosyal Bilimler Dergisi 95, 177-209. https://doi. org/10.12995/bilig.9508

Yaşar, E. (2019). Dış ticarette uluslararası mal ve piyasa çeşitlendirmesi: seçilmiş ülkeler için kümeleme analizi. İ̧̧letme ve iktisat Çalışmaları Dergisi, 7 (2), 85-106.

Yayla M. (2007). Türk bankacilık sektöründe yoğunlaşma ve rekabet: 1995-2005. BDDK Bankacılık ve Finansal Piyasalar Dergisi, Cilt:1, (1). https://dergipark.org.tr/tr/pub/bddkdergisi/issue $/ 57368 / 812766$

Yılmaz, F., \& Akkaya, G. C. (2020). Türkiye'nin Avrupa Birliği ile dış ticaretinde yoğunlaşma analizi. Çukurova Üniversitesi IiBF Dergisi, Cilt: 24(2), 251-267. https://dergipark.org.tr/tr/pub/cuiibfd/ issue $/ 60073 / 795206$ 